\title{
Matrix metalloproteinases and their specific tissue inhibitors in menstruation
}

\author{
Ji-Cui Dong, Hongguang Dong, Aldo Campana and Paul Bischof* \\ Department of Obstetrics and Gynaecology, University Hospital of Geneva, \\ 1211 Geneva, Switzerland
}

\begin{abstract}
The timely breakdown of extracellular matrix is essential for menstruation. Matrix metalloproteinases, which are able to degrade virtually all components of the extracellular matrix, are spatiotemporally expressed in the cyclic endometrium. The expression of most matrix metalloproteinases is regulated transcriptionally and their proteolytic activities are precisely controlled. The balance between matrix metalloproteinases and their specific tissue inhibitors is believed to be crucial for menstruation. This review focuses on the roles of matrix metalloproteinases and their tissue inhibitors in the initiation of menstruation and on the regulation of matrix metalloproteinase expression and activation. For example, the function of matrix metalloproteinases and their tissue inhibitors in endometrial re-epithelialization and angiogenesis during endometrial regeneration, when cell migration is facilitated to ensure endometrial repair, is discussed. This and other processes, although not fully resolved, serve to illustrate the involvement of matrix metalloproteinases and their tissue inhibitors in the process of menstruation.
\end{abstract}

Human endometrium is a dynamic tissue that undergoes extensive cyclic degradation and renewal. It has been a target tissue for the study of sex steroid and morphophysiologic interaction. The functional layer of the endometrium is shed and discharged at menstruation as a result of declining steroid support (Fox, 1973). Menstruation is associated with damage to the epithelium, interstitium, endothelium and extracellular matrix (ECM), resulting in controlled bleeding, tissue dissolution and repair (Bulletti et al., 1998). Despite the considerable progress made in understanding normal menstruation, the biochemical and cellular mechanisms involved remain poorly understood.

Matrix metalloproteinases (MMPs) form a family of homologous zinc-dependent enzymes collectively capable of degrading most proteins of the ECM at neutral $\mathrm{pH}$. Several laboratories have identified MMP expression in the endometrium (Marbaix et al., 1992; Martelli et al., 1993; Rodgers et al., 1994). A marked increase in endometrial expression of several MMPs occurs just before and during menstruation (Hampton and Salamonsen, 1994; Rodgers et al., 1994). The specific spatial and temporal expression patterns of MMPs indicate their pivotal roles in the process of menstruation (Salamonsen and Woolley, 1996). As the activity of all MMPs can be inhibited by tissue inhibitors of metalloproteinase (TIMPS) in a 1:1 stoichiometry (Docherty et al., 1985) and since TIMPs are also distributed in the

*Correspondence

Email: Paul.bischof@hcuge.ch endometrium throughout the menstrual cycle (Rodgers et al., 1994; Freitas et al., 1999), the balance between MMPs and TIMPs is likely to be critical for menstruation (Hampton and Salamonsen, 1994).

\section{Matrix metalloproteinases and their specific tissue inhibitors}

MMPs form a multigene family of enzymes (Table 1 ) that share significant sequence arrangement and a common multidomain structure, but are glycosylated to different extents and at different sites. With the exception of membranetype (MT)-MMPs, MMPs are extracellular enzymes that are secreted as inactive proenzymes (zymogens). These proenzymes consist of an $\mathrm{N}$-terminal propeptide domain of about 80 amino acids followed by a catalytic domain of about 170 residues. With the exception of matrilysin (MMP-7) and MMP-26, all catalytic domains are bound covalently via a proline-rich linker of 10-70 residues to a C-terminal haemopexin-like domain of about 195 residues (Massova et al., 1998; Bode et al., 1999). The haemopexinlike domain may determine the substrate specificity of MMPs or play a functional role in their interaction with TIMPs (Massova et al., 1998). In addition, MMP-2 and MMP-9 contain three repeats of a fibronectin type II-like domain that are inserted within their catalytic domain. In MT-MMPs, the polypeptide chain possesses an additional 75-100 residues, which form a transmembrane helix and a small cytoplasmatic domain (Sato et al., 1996).

Zymogens become activated upon limited hydrolysis, 
Table 1. Classification of human matrix metalloproteinases (MMPs)

\begin{tabular}{|c|c|c|c|c|c|c|}
\hline Subfamily & MMP & Other names & $\begin{array}{l}\text { Molecular } \\
\text { mass }(\mathrm{Da})^{\mathrm{a}}\end{array}$ & $\begin{array}{l}\text { Location } \\
\text { of gene }\end{array}$ & Substrates & $\begin{array}{l}\text { Accession } \\
\text { number }\end{array}$ \\
\hline \multirow[t]{3}{*}{ Collagenases } & MMP-1 & $\begin{array}{l}\text { Interstitial collagenase } \\
\text { Fibroblast collagenase }\end{array}$ & 54007 & Chromosome 11 & $\begin{array}{l}\text { Col I, II, III, VII and X; gelatins; entactin; } \\
\text { aggrecan; link protein }\end{array}$ & P03956 \\
\hline & MMP-8 & $\begin{array}{l}\text { Neutrophil collagenase } \\
\text { PMNL collagenase }\end{array}$ & 53412 & Chromosome 11 & Col I, II and III; aggrecan; link protein & P22894 \\
\hline & MMP-13 & Collagenase 3 & 53819 & Chromosome 11 & Col I, II and III & P45452 \\
\hline \multirow[t]{2}{*}{ Gelatinases } & MMP-2 & $\begin{array}{l}\text { Gelatinase A } \\
72 \text { kDa Gelatinase }\end{array}$ & 73882 & Chromosome 16 & $\begin{array}{l}\text { Gelatins; col I, IV, V, VII, X and XI; } \\
\text { fibronectin; laminin; aggrecan; elastin; } \\
\text { large tenascin C; vitronectin, } \beta \text {-amyloid } \\
\text { protein precursor }\end{array}$ & P08253 \\
\hline & MMP-9 & $\begin{array}{l}\text { Gelatinase B } \\
92 \text { kDa Gelatinase }\end{array}$ & 78427 & Chromosome 20 & $\begin{array}{l}\text { Gelatins; col IV, V and XIV; aggrecan; } \\
\text { elastin; entactin; vitronectin }\end{array}$ & P14780 \\
\hline \multirow[t]{5}{*}{ Stromelysins } & MMP-3 & $\begin{array}{l}\text { Stromelysin-1 } \\
\text { Transin-1 }\end{array}$ & 53977 & Chromosome 11 & $\begin{array}{l}\text { Aggrecan; col III, IV, IX and X; gelatins; } \\
\text { fibronectin; laminin; large tenascin-C; } \\
\text { vitronectin; elastin; casein }\end{array}$ & P08254 \\
\hline & MMP-7 & $\begin{array}{l}\text { Matrilysin } \\
\text { PUMP-1 }\end{array}$ & 29677 & Chromosome 11 & $\begin{array}{l}\text { Aggrecan, IGFBP-1; fibronectin; } \\
\text { laminin; gelatins; elastin; col IV; } \\
\text { entactin; small tenascin C; } \\
\text { vitronectin; casein }\end{array}$ & P09237 \\
\hline & MMP-10 & $\begin{array}{l}\text { Stromelysin-2 } \\
\text { Transin-2 }\end{array}$ & 54151 & Chromosome 11 & $\begin{array}{l}\text { Aggrecan; col II, IV and V; fibronectin; } \\
\text { gelatins; weakly col III, IV and V; } \\
\text { activate procollagenase }\end{array}$ & P09238 \\
\hline & MMP-11 & Stromelysin-3 & 54595 & Chromosome 22 & $\begin{array}{l}\text { Weak activity on fibronectin; laminin; } \\
\text { col IV; aggrecan; gelatins; IGFBP-1; } \\
\alpha 1 \text {-proteinase inhibitor }\end{array}$ & P24347 \\
\hline & MMP-12 & Metalloelastase & 54001 & Chromosome 11 & Elastin; fibronectin & P39900 \\
\hline \multirow[t]{6}{*}{$\begin{array}{l}\text { Membrane- } \\
\text { type MMPs }\end{array}$} & MMP-14 & $\begin{array}{l}\text { MT1-MMP } \\
\text { MMP-X1 }\end{array}$ & 65883 & Chromosome 14 & $\begin{array}{l}\text { Col I, II and III; fibronectin; laminin-1; } \\
\text { vitronectin; dermatan sulphate } \\
\text { proteoglycan; activates proMMP-2, } \\
\text { proMMP-13 }\end{array}$ & P50281 \\
\hline & MMP-15 & MT2-MMP & 75807 & Chromosome 16 & Activates pro-MMP-2 & P51511 \\
\hline & MMP-16 & MT3-MMP & 69521 & Chromosome 8 & Activates proMMP-2 & P51512 \\
\hline & MMP-17 & MT4-MMP & 67123 & Chromosome 12 & FibrinQ9ULZ9 & \\
\hline & MMP-24 & MT5-MMP & 73231 & Chromosome 20 & Activates proMMP-2 & Q9Y5R2 \\
\hline & MMP-25 & MT6-MMP & 62554 & Chromosome 16 & Activates proMMP-2 & Q9NPA2 \\
\hline \multirow[t]{4}{*}{ Others } & MMP-19 & MMPase RASI & 57357 & Chromosome 12 & Aggrecan & Q99542 \\
\hline & MMP-20 & Enamelysin & 54413 & Chromosome 11 & Amelogenin & O60882 \\
\hline & MMP-23 & MIFR/FEMAL-YSIN & 43934 & Chromosome 1 & & Q9UBR9 \\
\hline & MMP-26 & $\begin{array}{l}\text { Matrilysin-2 } \\
\text { Endometase }\end{array}$ & 29708 & Chromosome 11 & Gelatin; $\beta$-casein; fibronectin & Q9NRE1 \\
\hline
\end{tabular}

Information from Swiss-Prot database at www.expasy.ch/sprot/

Col: collagen; IGFBP-1: insulin-like growth factor binding protein 1; MIFR: metalloproteinase in the female reproductive tract; RASI: rheumatoid arthritis synovial inflammation.

${ }^{\mathrm{a} C}$ alculated from the number of amino acids. 
Table 2. Human tissue inhibitors of metalloproteinases (TIMPs)

\begin{tabular}{|c|c|c|c|c|c|}
\hline TIMP & Other names & $\begin{array}{l}\text { Molecular } \\
\text { mass }(\mathrm{Da})^{\mathrm{a}}\end{array}$ & $\begin{array}{l}\text { Location } \\
\text { of gene }\end{array}$ & $\begin{array}{l}\text { Matrix metalloproteinase } \\
(\mathrm{MMP}) \text { substrate }\end{array}$ & $\begin{array}{l}\text { Accession } \\
\text { number }\end{array}$ \\
\hline TIMP-1 & $\begin{array}{l}\text { Metalloprotease inhibitor } 1 \\
\text { Erytroid potentiating activity (EPA) } \\
\text { Fibroblast collagenase inhibitor } \\
\text { Collagenase inhibitor }\end{array}$ & 23171 & Chromosome X & MMP-1, 2, 3, 7, 8, 9, 10, 11, 12, 13, 16 & P01033 \\
\hline TIMP-2 & $\begin{array}{l}\text { Metalloprotease inhibitor } 2 \\
\text { CSC- } 21 \mathrm{~K}\end{array}$ & 24399 & Chromosome 17 & MMP-1, 2, 3, 7, 8, 9, 10, 13, 14, 15, 16, 19 & P16035 \\
\hline TIMP-3 & $\begin{array}{l}\text { Metalloprotease inhibitor } 3 \\
\text { MIG-5 protein }\end{array}$ & 24145 & Chromosome 22 & MMP-1, 2, 3, 7, 9, 13, 14, 15 & P35625 \\
\hline TIMP-4 & Metalloprotease inhibitor 4 & 25502 & Chromosome 3 & MMP-1, 2, 3, 7,9 & Q99727 \\
\hline
\end{tabular}

Information from Swiss-Prot database at www.expasy.ch/sprot/

CSC-21K: cystein-serine-cystein 21K; MIG-5: mitogen-inducible gene 5.

${ }^{\mathrm{a} C a l c u l a t e d}$ from the number of amino acids.

during which the propeptide is lost. Activation of the proMMPs into active MMPs can be reproduced in vitro by addition of different agents such as mercurial salts, plasmin or trypsin. Although the physiological activation of the different MMPs is poorly understood, plasmin (Eeckhout and Vaes, 1977) and MMP-3 (Birkedal-Hansen et al., 1993) have been shown to be potent activators of several MMPs.

MMPs play a critical role in many physiological processes such as wound healing, bone growth, nerve outgrowth, ovulation, embryo implantation, embryonic development, uterine involution and menstruation. Overexpression of MMPs is also linked to pathological processes such as tumour invasion and metastasis, arthritis and atherosclerosis.

TIMPs (Table 2) are the major endogenous inhibitors of MMP activities in tissues (Nagase and Woessner, 1999). Binding of TIMPs to the catalytic domain results in efficient inhibition of the enzymatic activity of MMPs (Massova et al., 1998). The TIMP family includes four proteins, TIMP$1-4$, which share some sequence identity $(40,30$ and $37 \%$ between TIMP-1 and TIMP-2, -3 and -4, respectively) (Douglas et al., 1997). Although TIMPs do not seem to differentiate much among the various MMPs, a certain degree of specificity has been observed. For example, TIMP-2 and -3, unlike TIMP-1, are effective inhibitors of MT-MMPs, whereas TIMP-1 preferentially binds MMP-9 (Strongin et al., 1995).

TIMPs are multifunctional proteins. Besides inhibiting MMP, TIMPs have other functions such as growth factorlike and anti-angiogenic activity (Gomez et al., 1997). TIMP-1 also stimulates fibroblasts to produce MMP-1 (Clark et al., 1994). TIMP-1 and -2 bind not only to activated gelatinases but also to proMMP-9 and -2, respectively (Strongin et al., 1995). The complex between MT1-MMP and TIMP-2 acts as a cell surface 'receptor' for proMMP-2 activation in vivo (Butler et al., 1998).

\section{Respective roles of MMPs and TIMPs in the process of menstruation}

\section{Role of MMPs and TIMPs in the onset of menstruation}

Markee (1948) used intraocular endometrial transplants in rhesus monkeys to determine that menstruation was initiated by the rapid regression of endometrial thickness as a result of fluid loss and tissue lysis, which were followed by intense vasoconstriction of the spiral arterioles and subsequent bleeding from focal points. Regression of the endometrium was later observed in non-menstruating mammals. The endometrial wet mass and collagen content of cyclic rats decrease during metoestrus to $20 \%$ of their value at pro-oestrus (Yochim and Blahna, 1976), indicating that proteolysis of the ECM takes part in this regression (Eeckhout, 1990). Even before bleeding commences, small lesions in human endometrial luminal epithelium can be seen under an electron microscope (Ludwig and Spornitz, 1991); these lesions contribute to the very rapid but incomplete degeneration of the functional layer and exposure of open capillary vessels. Widespread degeneration of human endometrial stroma and basal lamina occurs at the end of the luteal phase (Roberts et al., 1992). The classic view that menstruation is a process generated primarily by vascular events is thus challenged by the concept that breakdown of the ECM in the functionalis initiates menstruation.

A large number of studies strongly implicated MMPs and TIMPs in menstruation. Studies using immunocytochemistry (Martelli et al., 1993; Rodgers et al., 1993) or in situ hybridization (Hampton and Salamonsen, 1994; Rodgers et al., 1994) showed that endometrial cells produce MMP-1, -2, -3, -7 and -9, and TIMP-1 and -2. Messenger RNAs for proMMP-1 and -3 are detected in normal endometrium only peri-menstrually and menstrually. Therefore, it is likely that both MMP-1 and -3 have 
important roles in the tissue degradation that initiates menstruation (Hampton and Salamonsen, 1994). mRNAs encoding TIMP-1 and -2 are present throughout the cycle but increase to a lesser extent than do mRNAs encoding MMP on days 1 and 2 at menstruation (Hampton and Salamonsen, 1994). Given that the stability of mRNAs encoding MMPs and TIMPs is equivalent and that translation of the mRNAs results in the production of proteins in endometrial tissue, a major alteration in the balance between enzymes and their inhibitors is in favour of tissue degradation (Salamonsen and Woolley, 1996). Endometrial MMPs have different cellular origin. Observations in vivo and in vitro indicate that human endometrial stromal and epithelial cells, when cultured separately, can release several MMPs (Martelli et al., 1993). Most MMPs are produced by stromal cells at menstruation (Rawdanowicz et al., 1994; Rodgers et al., 1994). MMP-2 and -9 have a stromal expression throughout the menstrual cycle. MMP-9 is detected in the glandular epithelium but only during the secretory phase (days 19-20) (Freitas et al., 1999). An immunocytochemical study (Freitas et al., 1999) showed that MMP-2, -3 and -9 were also detected in endometrial vascular structures, such as pericytes and smooth muscle cells. In particular, MMP-3 was expressed in vessels during the pre-menstrual and menstrual phases. The abundant expression of MMP-3 in the vessels situated in the superficial layer of the endometrium during menses indicates that it initiates degradation of the vascular wall during menstrual breakdown. The occurrence of MMPs in both stromal and vascular compartments at the beginning of menstruation indicates that bleeding results from degradation of both stromal components and vascular walls (Freitas et al., 1999).

MMP-7 is also clearly related to menses as mRNA encoding MMP-7 has been localized to endometrial glandular and luminal epithelial cells, and reaches a peak concentration in the pre-menstrual and menstrual phases (Rodgers et al., 1993). However, the role of MMP-7 in the degradation of epithelial tissue remains to be investigated.

In addition to stromal cells, epithelial cells, endothelial cells and vascular smooth muscle cells (SMCs), the endometrium contains many different bone marrow-derived cells, including macrophages, T cells, B cells and granulocytes, which colonize the endometrium at each cycle. Leucocytes represent an increasing proportion of endometrial cells as the menstrual cycle progresses (Shi et al., 1995). Large granular lymphocytes (LGLs), T cells, B cells and macrophages also secrete MMP-2 and MMP-9 (Shi et al., 1995). LGLs release the highest gelatinolytic activity, followed by the macrophages, $T$ cells, $B$ cells and monocytes. Although gelatinolytic activity does not represent the total proteolytic activity of these cells, the contribution of these bone marrow-derived cells to the total proteolytic potential of the endometrium is quantitatively greater than the contribution of the epithelial and stromal cells after ovulation (Bischof, 1997).

The spatiotemporal expression and activation of MMPs in the endometrium is closely associated with the process of normal menstruation (Hampton and Salamonsen, 1994; Rodgers et al., 1994; Salamonsen and Woolley, 1996). The fact that synthetic MMP inhibitors completely inhibit the breakdown of menstrual tissue in vitro is taken as evidence for the instrumental role of MMPs in the onset of menstruation (Marbaix et al., 1996).

Norplant is an effective and widely used progestin-only contraceptive, which has a high discontinuation rate owing to unpredictable uterine bleeding. Expression of MMP-9 (Vincent et al., 1999) and MMP-1 (Vincent et al., 2000) is significantly higher in endometrial tissues from users of Norplant as compared with non-users. Irregular bleeding in women treated with Norplant correlates with the appearance of MMP-1 and -3 and the increased production of MMP-2, the activation of proMMP-1, -2, -3 and -9 and the decreased secretion of TIMP-1 (Galant et al., 2000; Marbaix et al., 2000). These findings imply that irregular bleeding occurs when the concentration of active MMPs exceeds the inhibitory capacity of TIMP-1, so as to freely degrade the ECM.

\section{Putative role of MMPS and TIMPs in endometrial regeneration}

Endometrial regeneration usually begins by the second day after bleeding has started (Smith, 2001). Epithelial cell migration followed by replication characterizes the biodynamics of endometrial surface repair (Bulletti et al., 1998). Bleeding stops when the surface has been completely re-epithelialized.

Heterogeneous expression of TIMP-1 and TIMP-2 occurs in arteriolar SMCs and in the stroma during menstruation, and staining occurs in non-necrotic tissue and is especially abundant in the arterioles, delimiting necrotic from nonnecrotic areas. This expression pattern implies that TIMPS limit the action of MMPs in some areas, thus preserving the capacity of endometrial regeneration (Freitas et al., 1999).

The roles of MMPs and TIMPs during endometrial repair have not been elucidated in detail. Most of our understanding derives from studies carried out on wound healing in skin.

It is generally accepted that migration and remodelling events during skin repair require both the activity of MMPs and their counter-regulation by TIMPs. After injury, an elaborate chain of events is triggered to ensure that basal keratinocytes migrate to re-epithelialize the wound (Martin, 1997). Increased MMP and plasmin expression is critical for the leading keratinocytes to dissolve the fibrin barrier around them, thereby facilitating their locomotion. Once the wound has been covered, the keratinocytes stop proliferating and switch off their MMP secretion (Martin, 1997). A similar expression pattern of MMPs in migrating epithelium has been found regardless of wound types and species (Saarialho-Kere et al., 1994; Salo et al., 1994; Kahari and Saarialho-Kere, 1997; Madlener et al., 1998). Although endometrial regeneration differs from wound 
healing because no scarring occurs, it is still reasonable to speculate that MMPs and TIMPs participate in the process of endometrial re-epithelialization.

Mechanisms of endometrial repair include angiogenesis, the process of new blood vessel formation from pre-existing blood vessels (Folkman, 1997). Angiogenesis consists of a sequence of events, including dissolution of the basement membrane underlying the endothelial layer, migration and proliferation of endothelial cells, formation of the vascular capillary, and formation of a new basement membrane (Sang, 1998). Angiogenesis can occur by sprouting or nonsprouting mechanisms. The pleiotropic effects of most MMPs and TIMPs in the angiogenic process have been reviewed in detail by Sang (1998). For example, MMP-2 and -9 activities are important in the early steps of endothelial capillary formation. MMP-1 activity is responsible for endothelial cell migration through the interstitial spaces. TIMP-1, -2, -3 and possibly -4 inhibit neovascularization through anti-MMP-dependent or -independent pathways. Fibrinolysis by the plasma membrane-anchored MT1-MMP in endothelial cells is critical for neovascularization (Hiraoka et al., 1998). Furthermore, mice made genetically deficient in MMP-2, although revealing no gross developmental abnormalities, have an impaired angiogenic response to tumour stimuli (Itoh et al., 1998). Targeted inactivation of MMP-9 causes a transient delay in bone development because of defective vascular invasion (Vu et al., 1998). Overexpression of the multipotent fibroblast growth factor 1 (FGF-1) stimulates endothelial cell migration by mediating MMP-1 gene transcription and collagenolytic activity (Partridge et al., 2000).

Angiogenesis is an essential component of endometrial renewal, because new blood vessel formation is required to supply oxygen and nutrients. Disruption of angiogenesis in mice results in endometrial atrophy (Klauber et al., 1997). Endometrial angiogenesis was characterized by non-sprouting mechanisms such as intussusception and elongation (Rogers and Gargett, 1999). In humans, growth of endometrial endothelial cells begins at menstruation and starts from the ruptured spiral arterioles and venules (Smith, 1998).

Vascular endothelial growth factor (VEGF) is the main angiogenic and permeability factor of the endometrium, and is involved in both physiological endometrial angiogenesis and endometriotic angiogenesis (Shifren et al., 1996). VEGF expression is controlled by ovarian steroids in proliferative and secretory endometrium (Shifren et al., 1996). During menstruation, local factors, such as hypoxia, can upregulate VEGF expression and this may play an important role in angiogenesis and endometrial repair after menstruation (Sharkey et al., 2000). Emerging evidence demonstrates that VEGF can induce MMP expression and inhibit TIMP expression in endothelial cells (Lamoreaux et al., 1998). VEGF can also stimulate MMP secretion from human aortic SMCs (Wang and Keiser, 1998). Both endothelial cell- and SMC-derived MMPs may facilitate degradation of vascular basement membrane, which is a crucial stage of angiogenesis. Upregulated SMC-derived MMPs may also promote SMC migration in a later stage of angiogenesis (Wang and Keiser, 1998). Thrombospondin type 1 (TSP1) is thought to function as an inhibitor of angiogenesis (Bein and Simons, 2000) and is expressed in endometrial stromal cells (Iruela-Arispe et al., 1996). TSP1 can prevent the activation of MMP-2 and -9 zymogens, which probably contributes to the anti-angiogenic activity of TSP1 (Bein and Simons, 2000). In this respect, it is perhaps significant that, in the endometrium, MMP-2, TIMP-1 and -2 are detectable in vessels throughout the menstrual cycle (Freitas et al., 1999). MMP-2 is expressed intensely in capillaries and SMCs at the end of the luteal phase. MMP-3 is expressed markedly in SMCs and in the basal portion of endothelial cells during the pre-menstrual and menstrual period. In contrast, MMP-9 is detected in spiral arteries during the secretory phase and in vascular structures during the midfollicular and menstrual phases. Taken together, these observations indicate that MMPs and TIMPs actively take part in the vascular events accompanying endometrial regeneration. A delicate shift in the balance between MMPs and their inhibitors occurs probably within the capillaries or in their environment during endometrial angiogenesis.

\section{Regulation of MMP gene expression}

Acute progesterone withdrawal induces both secretion and activation of certain MMPs (Martelli et al., 1993; Hampton and Salamonsen, 1994; Rodgers et al., 1994; Lockwood et al., 1998). In contrast, physiological concentrations of progesterone almost totally abolish MMP-1 release, as well as MMP-2 and -9 activity, in explant cultures of human endometrium (Marbaix et al., 1992). Therefore, it may be hypothesized that the expression of several MMPs in the human endometrium is controlled ultimately by ovarian steroids. In parallel to endometrial tissue changes, the temporal and spatial expression pattern of MMPs indicates the involvement of autocrine-paracrine regulations. The only study in vivo of the effects of steroids on the expression of MMPs and TIMPs in the endometrium of a primate (Rudolph-Owen et al., 1998) showed that, although endometrial MMPs were upregulated by withdrawal of progesterone in ovariectomized monkeys, many of the MMP transcripts decreased either abruptly or gradually after menstruation in the absence of progesterone. However, MMP expression was confined to the upper functionalis zone during menstruation, but after menstrual breakdown was complete, and expression of MMP-7 and TIMP-1 shifted from the functionalis to the basalis zone in the absence of both oestradiol and progesterone. Therefore, it seems unlikely that progesterone is the only hormone involved in regulating the expression, localization and function of endometrial MMPs.

Cell-cell interaction has an important role in mediating aspects of steroid action during growth and differentiation in the endometrium (McClellan et al., 1986). After the 
withdrawal of progesterone, there is a marked endometrial stromal compaction that increases cell-cell contacts. Regulation of MMP expression has been associated with changes both in the shape of cells and in cell contacts (Aggeler et al., 1984; James et al., 1993). Osteen et al. (1994) used isolated and recombined types of endometrial cell to demonstrate that isolated human endometrial epithelial cells require the presence of stromal cells to restore steroid suppression of MMP-7 secretion, confirming the necessity for stromal-derived factors as mediators in this suppression process. The number of lymphomyeloid cells (for example, eosinophils, macrophages and neutrophils) increases markedly in the endometrium during the pre-menstrual phase, and these cells synthesize a plethora of cytokines and proteases, including MMPs (Salamonsen and Woolley, 1999). Mast cell activation, which results in the release of potent regulators, such as tumour necrosis factor $\alpha$ (TNF- $\alpha$ ), interleukin 1 (IL-1), histamine, heparin, tryptase and chymase (Salamonsen and Lathbury, 2000), increases immediately before menstruation (Jeziorska et al., 1995).

Expression of endometrial MMPs can be regulated by locally produced cytokines and growth factors or by products of migratory or resident cells (Bischof and Campana, 2000). Transforming growth factor $\beta$ (TGF- $\beta$ ) is produced by endometrial stromal cells in response to progesterone, and this cytokine can suppress expression of epithelial MMP-7 independently of progesterone. Indeed, antibodies against TGF- $\beta$ abolish progesterone-induced MMP-7 suppression in stromal-epithelial cell co-cultures (Bruner et al., 1995). IL- $1 \alpha$ derived from the epithelium is the key paracrine inducer of MMP-1 in endometrial fibroblasts in the absence of ovarian steroids (Singer et al., 1997). IL-1 and TNF- $\alpha$ derived from human mast cells may stimulate production of stromal cell proMMP-1, -3 and, to a lesser extent, -2 (Zhang et al., 1998). Several recombinant cytokines can induce the selective expression of MMPs in cultured human endometrial fibroblasts: MMP-1 was induced by epidermal growth factor (EGF), platelet-derived growth factor-BB (PDGF-BB), TNF- $\alpha$ and IL- $1 \alpha$; mRNA encoding MMP-11 was induced concomitantly on treatment with insulin-like growth factor II (IGF-II) or IL-6 and, particularly, with EGF and PDGF-BB; and mRNA encoding MMP-9 was induced quickly by TNF- $\alpha$, but disappeared within $12 \mathrm{~h}$ despite continuing stimulation (Singer et al., 1999).

Cultured human endometrial stromal cells mimic menstruation-related events with remarkable fidelity. For example, Lockwood et al. (1998) demonstrated changes in vitro in MMP-1 and -3 mRNA and protein and an absence of effect on MMP-2 and TIMP-1 expression consistent with the results of the in situ hybridization study of Rodger et al. (1994). These results are consistent with the notion that some MMPs (MMP-1, -3 and -9) are regulated whereas others are constitutively expressed (MMP-2). Indeed, MMPs can be divided into two groups according to their regulation of gene expression: most MMPs exhibit inducible expression and a small number are produced constitutively and are not inducible (Borden and Heller, 1997). The promoter regions of inducible MMP genes (MMP-1, -3, -7, $-9,-10,-12$ and -13 ; Fig. 1) have a remarkable conservation of important regulatory cis elements, such as activator protein 1 (AP-1) and polyomavirus enhancer element (PEA3) (Westermarck and Kahari, 1999). Most of these genes are not expressed in unstimulated cells, and their expression is induced markedly by growth factors, cytokines, chemical agents (for example, phorbol esters and actin stress fibre-disrupting drugs), physical stress, and oncogenic cellular transformation. In addition, the enhanced MMP gene expression may be downregulated by suppressive factors (for example, TGF- $\beta$, retinoic acid and glcocorticoids) (Nagase and Woessner, 1999). AP-1 is a homo- or heterodimeric DNA-binding protein composed of either two proteins of the Jun family or one protein of the Jun family and one protein of the Fos family (Westermarck and Kahari, 1999). In general, the AP-1 element seems to be important in initiating transcription of these genes, whereas PEA3 and possibly other sites contribute to the fine tuning mechanisms that modulate these genes (Matrisian, 1992). In contrast, MMP-2 is constitutively expressed. The promoter region of the MMP-2 gene (Fig. 1) contains an AP-2 binding site and two specificity protein 1 (SP-1) sites but lacks a TATA box and AP-1- and PEA-3binding sequences (Huhtala et al., 1990). The MT1-MMP promoter shows similarity with that of MMP-2 (Lohi et al., 2000).

Progesterone clearly acts to suppress endometrial MMP expression, but the mechanism of its regulation on transcription of specific MMP genes is not yet understood. The fact that the promoter region of most MMPs (both inducible and non-inducible MMPs) lacks traditional progesterone responsive elements indicates that progesterone may regulate certain MMP genes via nonclassical DNA sequences (Hulboy et al., 1997). In addition, ligandactivated progesterone receptor (PR), like other activated nuclear receptors, such as glucocorticoid receptor (YangYen et al., 1990), retinoic acid receptor (Schule et al., 1991) and thyroid receptor (Zhang et al., 1991), may decrease the amounts of transcription factors (such as fos-jun) by a direct protein-protein interaction, resulting in a decreased binding of the transcription factors on the AP-1 site of MMP promoters. When human PR (hPR) was transfected into hPR-devoid human endometrial (HEC-1-B) cells, AP-1 activity was stimulated by the mere presence of the receptor in the absence of progesterone or of any other stimulus, whereas addition of the ligand (progesterone) reversed the effect (Bamberger et al., 1996). Moreover, the influx of leucocytes (which are known to produce MMPs) into human endometrium coincides with progesterone withdrawal (Salamonsen and Lathbury, 2000), and so the progesterone decline may also provide cell-cell communication among the various migratory and resident cells and further influence local expression of MMPs. 


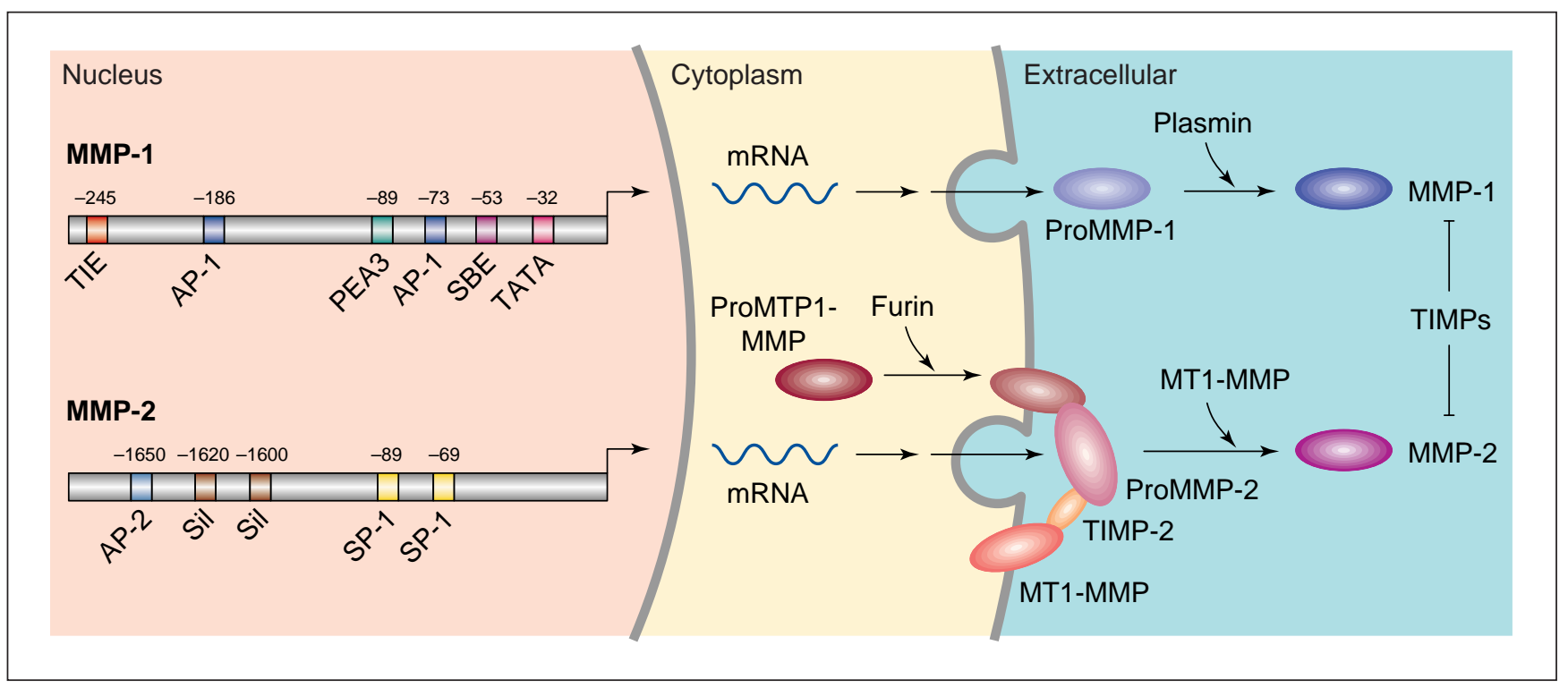

Fig. 1. Human matrix metalloproteinase (MMP) activity is controlled by transcriptional regulation, pro-enzyme activation and inhibition by specific tissue inhibitors (TIMPS). With respect to gene expression, MMP-1 and -2 represent examples of an inducible and an uninducible MMP, respectively. Human MMP-1 promoter region contains binding sites (activator protein 1 binding site (AP-1) and polyomavirus enhancer A binding protein 3 responsive element (PEA3)) that are responsive elements for several growth factors and cytokines. ProMMP-1 (like most MMPs) is activated extracellularly in a stepwise manner. Human MMP-2 promoter region lacks AP-1- and PEA3-binding sequences. ProMMP-2 is activated on the cell surface. This activation process requires both active membrane-type 1 (MT1)MMP- and TIMP-2-bound MT1-MMP. The TIMP-2 in this complex binds proMMP-2 to generate a ternary complex, which is assumed to bring the zymogen close to the active MT1-MMP. ProMT1-MMP is activated intracellularly by furin. TIE: TGF- $\beta$ inhibitory element; SBE: STAT binding element; SP-1: specificity protein 1 binding site; sil: silencer sequence.

\section{Control of MMP activation}

Apart from MMP-11 and most MT-MMPs, which are activated intracellularly by the Golgi-associated proteinase furin (Pei and Weiss, 1995, 1996), most MMPs are secreted from cells as inactive zymogens. In all cases, activation requires the disruption of the Cys- $\mathrm{Zn}^{2+}$ (cysteine switch) interaction, and the removal of the propeptide proceeds thereafter often in a stepwise manner (Nagase, 1997). Most pro-MMPs are likely to be activated by tissue proteinases or opportunistic bacterial proteinases in vivo (Nagase and Woessner, 1999). Studies in transgenic mice indicate that the urokinase plasminogen activator (uPA)-plasmin system is a key activator of pro-MMPs (Carmeliet et al., 1997). Studies in vitro using human endometrial stromal cells indicated that PA activity is regulated primarily by changes in the expression of plasminogen activator inhibitor 1 (PAI1) (Lockwood et al., 1995; Schatz et al., 1995), which is different from the regulation of expression of MMP, brought about primarily by changes in transcription of MMP that are independent of TIMP expression (Lockwood et al., 1998). Progesterone inhibits the secretion of PAs by cultured endometrial explants (Casslen et al., 1986) and stimulates the expression of PAI-1 by cultured endometrial stromal cells (Casslen et al., 1992), indicating a control of this system by sex steroids during the menstrual cycle and its release before menstruation (Marbaix et al., 1996).
Secreted pro-uPA binds to, and is activated at, specific cell membrane receptors, where it coverts plasminogen to plasmin. Plasmin may degrade matrices that undergo rapid turnover but also may exert its prime impact on ECM proteolysis by activating MMP zymogen (Eeckhout and Vaes, 1977).

Both mast cell tryptase and chymase may play roles in MMPs activation at menstruation. MMP-3, which initiates a cascade of MMP activation (Birkedal-Hansen et al., 1993), is activated by tryptase in human endometrial stromal cells (Zhang et al., 1998). In addition, chymase can activate latent MMP-1 (Saarinen et al., 1994).

MMP-2 is an exception. In tumour cells, endometrial neutrophils and endometrial granular leucocytes, activation of proMMP-2 has been shown to take place on the cell surface. MT1-MMP has been postulated to activate proMMP-2 in endometrium (Zhang et al., 2000). This activation process requires both active MT1-MMP and TIMP-2-bound MT1-MMP. The TIMP-2 in the latter complex binds proMMP-2 to generate a ternary complex, which is assumed to bring the zymogen close to the active MT1MMP (Butler et al., 1998). On angiogenic endothelial and melanoma cells, MMP-2 may be localized in a proteolytically active form on the cell surface through binding to the intergrin receptor $\alpha v \beta 3$ (Brooks et al., 1996). Meanwhile, the uPA-plasmin system associated with the cell surface can also activate surface-bound proMMP-2, 


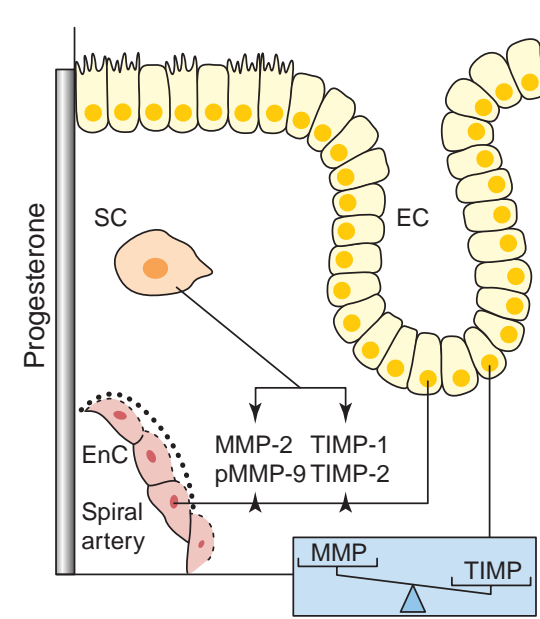

Secretory phase

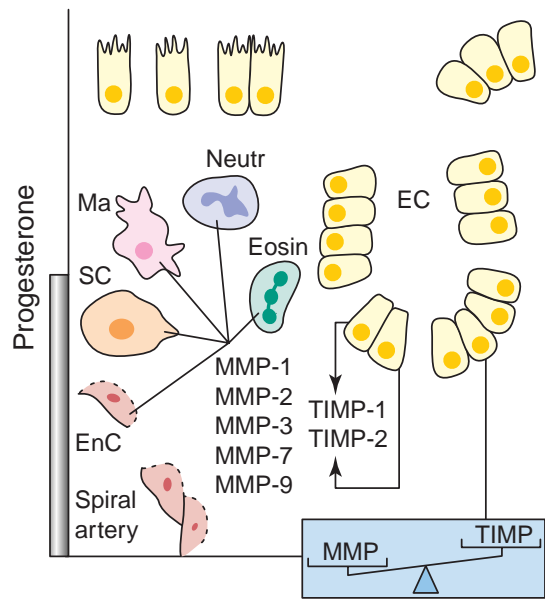

Menstrual phase 1

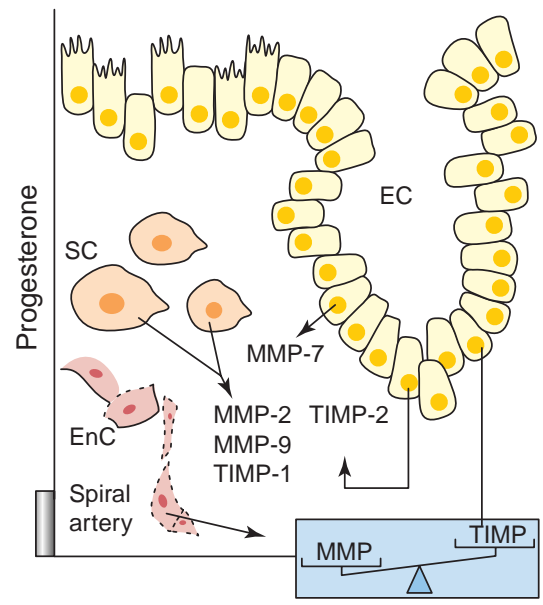

Menstrual phase 2

Fig. 2. During the secretory phase, endometrial matrix metalloproteinases (MMPs) and their tissue inhibitors (TIMPs) are secreted by several cells. It is likely that TIMPs override the activity of MMPs so that the net proteolytic activity is nil. During the first 2 days of the menstrual phase, leucocytes are attracted into the endometrium, a response that is triggered by progesterone withdrawal. These white cells, together with stromal (SC), endothelial (EnC) and epithelial cells (EC) produce important quantities of different MMPs, whereas production of TIMPs remains low, producing an increased proteolytic activity in the endometrium, and leading to destruction of the extracellular matrix and disruption of blood vessels, interstitium and epithelium. During the last 2 days of menses, MMP secretion is probably used for tissue repair, allowing keratinocytes to re-epithelialize the endometrial surface and helping endothelial cells to form new blood vessels. Eosin: eosinophils; Ma: macrophages; Neutr: neutophils.

whereas soluble plasmin degrades it (Mazzieri et al., 1997). In addition, MMP-2 can be activated through auto-lysis (Atkinson et al., 1995).

Active MMPs are inhibited by $\alpha_{2}$-macroglobulin or by TIMPs, which are both present in human endometrium throughout the menstrual cycle, and protect the endometrium from excessive tissue degradation.

\section{Conclusion}

Matrix metalloproteinases have diverse substrate specificity, ranging from multiple ECM components to growth factors, cytokines and other proteinases. Recent studies have increased our understanding of the significance of MMPs and TIMPs in the process of menstruation (Fig. 2). It is becoming clear that MMPs play a key role in the cyclical breakdown of ECM that ultimately leads to menstruation. Although circulating concentrations of progesterone affect the expression pattern of several endometrial MMPs, local factors can enhance or override this regulation. Although the cellular and molecular processes of endometrial repair are still unclear, MMPs cleave structural substances and fulfil additional regulatory roles (such as the processing of inactive MMP and cytokine precursors) and TIMPs exhibit multiple biological functions and, therefore, are likely to play a highly complex and tightly regulated role in endometrial repair. Some intriguing issues remain to be investigated. For example, which MMPs are the key enzymes in the initiation of menstruation; what are the respective contributions of the various MMPs in the process of endometrial repair; and how does progesterone influence leucocyte migration and activation?

\section{References}

Key references are identified by asterisks.

Aggeler J, Frisch SM and Werb Z (1984) Changes in cell shape correlate with collagenase gene expression in rabbit synovial fibroblasts Journal of Cell Biology 98 1662-1671

Atkinson SJ, Crabbe T, Cowell S, Ward RV, Butler MJ, Sato H, Seiki M, Reynolds JJ and Murphy G (1995) Intermolecular autolytic cleavage can contribute to the activation of progelatinase A by cell membranes Journal of Biological Chemistry 27030 479-30 485

Bamberger AM, Bamberger CM, Gellersen B and Schulte HM (1996) Modulation of AP-1 activity by the human progesterone receptor in endometrial adenocarcinoma cells Proceedings of the National Academy of Sciences USA 93 6169-6174

Bein K and Simons M (2000) Thrombospondin type 1 repeats interact with matrix metalloproteinase 2. Regulation of metalloproteinase activity Journal of Biological Chemistry 275 32167-32173

Birkedal-Hansen H, Moore WG, Bodden MK, Windsor LJ, Birkedal-Hansen B, DeCarlo A and Engler JA (1993) Matrix metalloproteinases: a review Critical Reviews in Oral Biology and Medicine 4 197-250

Bischof P (1997) Metalloproteinases and regulation of endometrial function. In The Endometrium as a Target for Contraception pp 123-136 Eds HM Beier et al. Springer, Heidelberg

Bischof P and Campana A (2000) Molecular mediators of implantation Bailliere's Best Practice and Research in Clinical Obstetrics and Gynaecology 14 801-814

Bode W, Fernandez-Catalan C, Tschesche H, Grams F, Nagase H and 
Maskos K (1999) Structural properties of matrix metalloproteinases Cellular and Molecular Life Science 55 639-652

Borden P and Heller RA (1997) Transcriptional control of matrix metalloproteinases and the tissue inhibitors of matrix metalloproteinases Critical Reviews in Eukaryotic Gene Expression 7 159-178

Brooks PC, Stromblad S, Sanders LC, von Schalscha TL, Aimes RT, StetlerStevenson WG, Quigley JP and Cheresh DA (1996) Localization of matrix metalloproteinase MMP-2 to the surface of invasive cells by interaction with integrin alpha v beta 3 Cell 85 683-693

Bruner KL, Rodgers WH, Gold LI, Korc M, Hargrove JT, Matrisian LM and Osteen KG (1995) Transforming growth factor beta mediates the progesterone suppression of an epithelial metalloproteinase by adjacent stroma in the human endometrium Proceedings of the National Academy of Sciences USA 92 7362-7366

Bulletti C, de Ziegler D, Albonetti A and Flamigni C (1998) Paracrine regulation of menstruation Journal of Reproductive Immunology 39 89-104

*Butler GS, Butler MJ, Atkinson SJ, Will H, Tamura T, van Westrum SS, Crabbe T, Clements J, d'Ortho MP and Murphy G (1998) The TIMP2 membrane type 1 metalloproteinase 'receptor' regulates the concentration and efficient activation of progelatinase A. A kinetic study Journal of Biological Chemistry 273 871-880

Carmeliet P, Moons L, Lijnen R et al. (1997) Urokinase-generated plasmin activates matrix metalloproteinases during aneurysm formation Nature Genetics 17 439-444

Casslen B, Andersson A, Nilsson IM and Astedt B (1986) Hormonal regulation of the release of plasminogen activators and of a specific activator inhibitor from endometrial tissue in culture Proceedings of the Society for Experimental Biology and Medicine 182 419-424

Casslen B, Urano S and Ny T (1992) Progesterone regulation of plasminogen activator inhibitor 1 (PAI-1) antigen and mRNA levels in human endometrial stromal cells Thrombosis Research 66 75-87

Clark IM, Powell LK and Cawston TE (1994) Tissue inhibitor of metalloproteinases (TIMP-1) stimulates the secretion of collagenase from human skin fibroblasts Biochemical and Biophysical Research Communications 203 874-880

Docherty AJ, Lyons A, Smith BJ, Wright EM, Stephens PE, Harris TJ, Murphy G and Reynolds JJ (1985) Sequence of human tissue inhibitor of metalloproteinases and its identity to erythroid-potentiating activity Nature 318 66-69

Douglas DA, Shi YE and Sang QA (1997) Computational sequence analysis of the tissue inhibitor of metalloproteinase family Journal of Protein Chemistry 16 237-255

Eeckhout Y (1990) Tissue breakdown. In Contraception and Mechanisms of Endometrial Bleeding pp 431-439 Eds C d'Arcanges et al. Cambridge University Press, Cambridge

Eeckhout Y and Vaes G (1977) Further studies on the activation of procollagenase, the latent precursor of bone collagenase. Effects of lysosomal cathepsin B, plasmin and kallikrein, and spontaneous activation Biochemical Journal 166 21-31

Folkman J (1997) Angiogenesis and angiogenesis inhibition: an overview EXS 79 1-8

Fox H (1973) The normal and abnormal endometrium. In Postgraduate Obsterical and Gynaecological Pathology pp 115-145 Eds H Fox and FA Langley. Pergamon, Oxford

*Freitas S, Meduri G, Le Nestour E, Bausero P and Perrot-Applanat M (1999) Expression of metalloproteinases and their inhibitors in blood vessels in human endometrium Biology of Reproduction 61 1070-1082

Galant C, Vekemans M, Lemoine P et al. (2000) Temporal and spatial association of matrix metalloproteinases with focal endometrial breakdown and bleeding upon progestin-only contraception Journal of Clinical Endocrinology and Metabolism 85 4827-4834

Gomez DE, Alonso DF, Yoshiji H and Thorgeirsson UP (1997) Tissue inhibitors of metalloproteinases: structure, regulation and biological functions European Journal of Cell Biology 74 111-122

*Hampton AL and Salamonsen LA (1994) Expression of messenger ribonucleic acid encoding matrix metalloproteinases and their tissue inhibitors is related to menstruation Journal of Endocrinology 141 R1-R3
Hiraoka N, Allen E, Apel IJ, Gyetko MR and Weiss SJ (1998) Matrix metalloproteinases regulate neovascularization by acting as pericellular fibrinolysins Cell 95 365-377

Huhtala P, Chow LT and Tryggvason K (1990) Structure of the human type IV collagenase gene Journal of Biological Chemistry 26511 077-11 082

Hulboy DL, Rudolph LA and Matrisian LM (1997) Matrix metalloproteinases as mediators of reproductive function Molecular Human Reproduction 3 27-45

Iruela-Arispe ML, Porter P, Bornstein P and Sage EH (1996) Thrombospondin-1, an inhibitor of angiogenesis, is regulated by progesterone in the human endometrium Journal of Clinical Investigation 97 403-412

Itoh T, Tanioka M, Yoshida H, Yoshioka T, Nishimoto $\mathbf{H}$ and Itohara $\mathbf{S}$ (1998) Reduced angiogenesis and tumor progression in gelatinase Adeficient mice Cancer Research 58 1048-1051

James TW, Wagner R, White LA, Zwolak RM and Brinckerhoff CE (1993) Induction of collagenase and stromelysin gene expression by mechanical injury in a vascular smooth muscle-derived cell line Journal of Cellular Physiology 157 426-437

Jeziorska M, Salamonsen LA and Woolley DE (1995) Mast cell and eosinophil distribution and activation in human endometrium throughout the menstrual cycle Biology of Reproduction 53 312-320

Kahari VM and Saarialho-Kere U (1997) Matrix metalloproteinases in skin Experimental Dermatology 6 199-213

Klauber N, Rohan RM, Flynn E and D'Amato RJ (1997) Critical components of the female reproductive pathway are suppressed by the angiogenesis inhibitor AGM-1470 Nature Medicine 3 443-446

Lamoreaux WJ, Fitzgerald ME, Reiner A, Hasty KA and Charles ST (1998) Vascular endothelial growth factor increases release of gelatinase $\mathrm{A}$ and decreases release of tissue inhibitor of metalloproteinases by microvascular endothelial cells in vitro. Microvascular Research 55 $29-42$

Lockwood CJ, Krikun G, Papp C, Aigner S and Schatz F (1995) Biological mechanisms underlying the clinical effects of RU 486: modulation of cultured endometrial stromal cell plasminogen activator and plasminogen activator inhibitor expression Journal of Clinical Endocrinology and Metabolism 80 1100-1105

Lockwood CJ, Krikun G, Hausknecht VA, Papp C and Schatz F (1998) Matrix metalloproteinase and matrix metalloproteinase inhibitor expression in endometrial stromal cells during progestin-initiated decidualization and menstruation-related progestin withdrawal Endocrinology139 4607-4613

Lohi J, Lehti K, Valtanen H, Parks WC and Keski-Oja J (2000) Structural analysis and promoter characterization of the human membrane-type matrix metalloproteinase-1 (MT1-MMP) gene Gene 242 75-86

Ludwig H and Spornitz UM (1991) Microarchitecture of the human endometrium by scanning electron microscopy: menstrual desquamation and remodeling Annals of the New York Academy of Sciences $\mathbf{6 2 2} 28-46$

McClellan M, West NB and Brenner RM (1986) Immunocytochemical localization of estrogen receptors in the macaque endometrium during the luteal-follicular transition Endocrinology 119 2467-2475

Madlener M, Parks WC and Werner S (1998) Matrix metalloproteinases (MMPs) and their physiological inhibitors (TIMPs) are differentially expressed during excisional skin wound repair Experimental Cell Research 242 201-210

Marbaix E, Donnez J, Courtoy PJ and Eeckhout Y (1992) Progesterone regulates the activity of collagenase and related gelatinases A and B in human endometrial explants Proceedings of the National Academy of Sciences USA 8911 789-11 793

*Marbaix E, Kokorine I, Moulin P, Donnez J, Eeckhout Y and Courtoy P (1996) Menstrual breakdown of human endometrium can be mimicked in vitro and is selectively and reversibly blocked by inhibitors of matrix metalloproteinases Proceedings of the National Academy of Sciences USA 93 9120-9125

Marbaix E, Vekemans M, Galant C et al. (2000) Circulating sex hormones and endometrial stromelysin-1 (matrix metalloproteinase-3) at the start of bleeding episodes in levonorgestrel-implant users Human Reproduction 15 Supplement 3 120-134 
Markee JE (1948) Morphological basis for menstrual bleeding: relation of regression to the initiation of bleeding Bulletin of the New York Academy of Medicine 24 253-268

Martelli M, Campana A and Bischof P (1993) Secretion of matrix metalloproteinases by human endometrial cells in vitro. Journal of Reproduction and Fertility 98 67-76

Martin P (1997) Wound healing - aiming for perfect skin regeneration Science 276 75-81

*Massova I, Kotra LP, Fridman R and Mobashery S (1998) Matrix metalloproteinases: structures, evolution, and diversification FASEB Journal 12 1075-1095

Matrisian LM (1992) The matrix-degrading metalloproteinases Bioessays 14 455-463

Mazzieri R, Masiero L, Zanetta L, Monea S, Onisto M, Garbisa S and Mignatti P (1997) Control of type IV collagenase activity by components of the urokinase-plasmin system: a regulatory mechanism with cellbound reactants EMBO Journal 16 2319-2332

Nagase H (1997) Activation mechanisms of matrix metalloproteinases Biological Chemistry 378 151-160

Nagase $\mathbf{H}$ and Woessner JF, Jr (1999) Matrix metalloproteinases Journal of Biological Chemistry $27421491-21494$

Osteen KG, Rodgers WH, Gaire M, Hargrove JT, Gorstein F and Matrisian LM (1994) Stromal-epithelial interaction mediates steroidal regulation of metalloproteinase expression in human endometrium Proceedings of the National Academy of Sciences USA 91 10 129-10133

Partridge CR, Hawker JR, Jr and Forough R (2000) Overexpression of a secretory form of FGF-1 promotes MMP-1-mediated endothelial cell migration Journal of Cellular Biochemistry 78 487-499

Pei D and Weiss SJ (1995) Furin-dependent intracellular activation of the human stromelysin-3 zymogen Nature 375 244-247

Pei D and Weiss SJ (1996) Transmembrane-deletion mutants of the membrane-type matrix metalloproteinase- 1 process progelatinase $\mathrm{A}$ and express intrinsic matrix-degrading activity Journal of Biological Chemistry 271 9135-9140

Rawdanowicz TJ, Hampton AL, Nagase H, Woolley DE and Salamonsen LA (1994) Matrix metalloproteinase production by cultured human endometrial stromal cells: identification of interstitial collagenase, gelatinase-A, gelatinase-B, and stromelysin-1 and their differential regulation by interleukin-1 alpha and tumor necrosis factor-alpha Journal of Clinical Endocrinology and Metabolism 79 530-536

Roberts DK, Parmley TH, Walker NJ and Horbelt DV (1992) Ultrastructure of the microvasculature in the human endometrium throughout the normal menstrual cycle American Journal of Obstetrics and Gynecology 166 1393-1406

Rodgers WH, Osteen KG, Matrisiann LM, Navre M, Giudice LC and Gorstein F (1993) Expression and localization of matrilysin, a matrix metalloproteinase, in human endometrium during the reproductive cycle American Journal of Obstetrics and Gynecology 168 253-260

*Rodgers WH, Matrisian LM, Giudice LC, Dsupin B, Cannon P, Svitek C, Gorstein F and Osteen KG (1994) Patterns of matrix metalloproteinase expression in cycling endometrium imply differential functions and regulation by steroid hormones Journal of Clinical Investigation 94 946-953

Rogers PAW and Gargett CE (1999) Endometrial angiogenesis Angiogenesis 2 287-294

*Rudolph-Owen LA, Slayden OD, Matrisian LM and Brenner RM (1998) Matrix metalloproteinase expression in Macaca mulatta endometrium: evidence for zone-specific regulatory tissue gradients Biology of Reproduction 59 1349-1359

Saarialho-Kere UK, Pentland AP, Birkedal-Hansen H, Parks WC and Welgus HG (1994) Distinct populations of basal keratinocytes express stromelysin-1 and stromelysin-2 in chronic wounds Journal of Clinical Investigation 94 79-88

Saarinen J, Kalkkinen N, Welgus HG and Kovanen PT (1994) Activation of human interstitial procollagenase through direct cleavage of the Leu83Thr84 bond by mast cell chymase Journal of Biological Chemistry 269 18134-18140

Salamonsen LA and Lathbury LJ (2000) Endometrial leukocytes and menstruation Human Reproduction Update 6 16-27
Salamonsen LA and Woolley DE (1996) Matrix metalloproteinases in normal menstruation Human Reproduction 11 Supplement 2 124-133

*Salamonsen LA and Woolley DE (1999) Menstruation: induction by matrix metalloproteinases and inflammatory cells Journal of Reproductive Immunology 44 1-27

Salo T, Makelan $\mathbf{M}$, Kylmaniemi $\mathbf{M}$, Autio-Harmainen $\mathbf{H}$ and Larjava $\mathbf{H}$ (1994) Expression of matrix metalloproteinase-2 and -9 during early human wound healing Laboratory Investigation 70 176-182

Sang QX (1998) Complex role of matrix metalloproteinases in angiogenesis Cell Research 8 171-177

Sato H, Kinoshita T, Takino T, Nakayama K and Seiki M (1996) Activation of a recombinant membrane type 1-matrix metalloproteinase (MT1-MMP) by furin and its interaction with tissue inhibitor of metalloproteinases (TIMP)-2 FEBS Letters 393 101-104

Schatz F, Aigner S, Papp C, Toth-Pal E, Hausknecht V and Lockwood CJ (1995) Plasminogen activator activity during decidualization of human endometrial stromal cells is regulated by plasminogen activator inhibitor 1 Journal of Clinical Endocrinology and Metabolism 80 2504-2510

Schule R, Rangarajan P, Yang N, Kliewer S, Ransone LJ, Bolado J, Verma IM and Evans RM (1991) Retinoic acid is a negative regulator of AP-1responsive genes Proceedings of the National Academy of Sciences USA 88 6092-6096

Sharkey AM, Day K, McPherson A, Malik S, Licence D, Smith SK and Charnock-Jones DS (2000) Vascular endothelial growth factor expression in human endometrium is regulated by hypoxia Journal of Clinical Endocrinology and Metabolism 85 402-409

Shi W, Mognetti B, Campana A and Bischof P (1995) Metalloproteinase secretion by endometrial leukocyte subsets American Journal of Reproductive Immunology 34 299-310

Shifren JL, Tseng JF, Zaloudek CJ, Ryan IP, Meng YG, Ferrara N, Jaffe RB and Taylor RN (1996) Ovarian steroid regulation of vascular endothelial growth factor in the human endometrium: implications for angiogenesis during the menstrual cycle and in the pathogenesis of endometriosis Journal of Clinical Endocrinology and Metabolism $813112-3118$

Singer CF, Marbaix E, Kokorine I, Lemoine P, Donnez J, Eeckhout Y and Courtoy PJ (1997) Paracrine stimulation of interstitial collagenase (MMP1) in the human endometrium by interleukin 1 alpha and its dual block by ovarian steroids Proceedings of the National Academy of Sciences USA $9410341-10345$

Singer CF, Marbaix E, Lemoine P, Courtoy PJ and Eeckhout Y (1999) Local cytokines induce differential expression of matrix metalloproteinases but not their tissue inhibitors in human endometrial fibroblasts European Journal of Biochemistry 259 40-45

Smith SK (1998) Angiogenesis, vascular endothelial growth factor and the endometrium Human Reproduction Update 4 509-519

Smith SK (2001) Regulation of angiogenesis in the endometrium Trends in Endocrinology and Metabolism 12 147-151

Strongin AY, Collier I, Bannikov G, Marmer BL, Grant GA and Goldberg GI (1995) Mechanism of cell surface activation of 72-kDa type IV collagenase. Isolation of the activated form of the membrane metalloprotease Journal of Biological Chemistry 270 5331-5338

Vincent AJ, Malakooti N, Zhang J, Rogers PA, Affandi B and Salamonsen LA (1999) Endometrial breakdown in women using Norplant is associated with migratory cells expressing matrix metalloproteinase-9 (gelatinase B) Human Reproduction 14 807-815

Vincent AJ, Zhang J, Ostor A, Rogers PA, Affandi B, Kovacs G and Salamonsen LA (2000) Matrix metalloproteinase-1 and -3 and mast cells are present in the endometrium of women using progestin-only contraceptives Human Reproduction 15 123-130

Vu TH, Shipley JM, Bergers G, Berger JE, Helms JA, Hanahan D, Shapiro SD, Senior RM and Werb Z (1998) MMP-9/gelatinase B is a key regulator of growth plate angiogenesis and apoptosis of hypertrophic chondrocytes Cell 93 411-422

Wang H and Keiser JA (1998) Vascular endothelial growth factor upregulates the expression of matrix metalloproteinases in vascular smooth muscle cells: role of flt-1 Circulation Research 83 832-840

Westermarck J and Kahari VM (1999) Regulation of matrix metalloproteinase expression in tumor invasion FASEB Journal 13 781-792 
Yang-Yen HF, Chambard JC, Sun YL, Smeal T, Schmidt TJ, Drouin J and Karin M (1990) Transcriptional interference between c-Jun and the glucocorticoid receptor: mutual inhibition of DNA binding due to direct protein-protein interaction Cell 62 1205-1215

Yochim JM and Blahna DG (1976) Effects of oestrone and progesterone on collagen and ascorbic acid content in the endometrium and myometrium of the rat Journal of Reproduction and Fertility 47 79-82

Zhang J, Nie G, Jian W, Woolley DE and Salamonsen LA (1998) Mast cell regulation of human endometrial matrix metalloproteinases: a mechanism underlying menstruation Biology of Reproduction 59 693-703

Zhang J, Hampton AL, Nie G and Salamonsen LA (2000) Progesterone inhibits activation of latent matrix metalloproteinase (MMP)-2 by membrane-type 1 MMP: enzymes coordinately expressed in human endometrium Biology of Reproduction 62 85-94

Zhang XK, Wills KN, Husmann M, Hermann T and Pfahl M (1991) Novel pathway for thyroid hormone receptor action through interaction with jun and fos oncogene activities Molecular and Cellular Biology 11 6016-6025 